\title{
Liquidity Risk Regulation
}

\author{
Tomáš Gongol ${ }^{1}$, Pavla Vodová ${ }^{2}$ \\ ${ }^{1}$ Silesian University in Opava \\ School of Business Administration in Karviná, Department of Law \\ Univerzitní nám. 1934/3, 73340 Karviná \\ E-mail: gongol@opf.slu.cz \\ ${ }^{2}$ Silesian University in Opava \\ School of Business Administration in Karviná, Department of Finance \\ Univerzitní nám. 1934/3, 73340 Karviná \\ E-mail: vodova@opf.slu.cz
}

\begin{abstract}
One of the key characteristics of the global financial crisis was the inaccurate and ineffective liquidity risk management. As usual after the crisis, some thoughts about the need for more appropriate liquidity risk regulation emerged. The aim of this paper is therefore to characterize the development of liquidity risk regulation. First part of the paper characterizes reasons for liquidity risk regulation. The second section describes the liquidity risk regulation before the financial crisis. Then we focus on the current level of legislation in the Visegrad Countries and also on prepared changes which will arise from the Basel III rules: minimum liquidity standards (Liquidity Coverage Ratio and Net Stable Funding Ratio) and the monitoring tools for liquidity risk.
\end{abstract}

Keywords: liquidity risk, financial crisis, regulation, Basel Committee on Banking Supervision

JEL codes: G01, G21

\section{Introduction}

The fundamental role of banks is to transform short-term deposits into long-term loans. However, because of this transformation, banks are exposed to liquidity risk. According to the Bank for International Settlements (BIS, 2008a), liquidity is the ability of a bank to fund increases in assets and meet obligations as they come due, without incurring unacceptable losses. Liquidity risk can be defined as the risk that a bank, though solvent, either does not have enough financial resources to allow it to meet its obligation as they fall due, or can obtain such funds only at excessive costs (Vento and La Ganga, 2009). The primary source of liquidity risk is due to the development of certain assets and liabilities. On the liability side, there is a large uncertainty about the volume of deposit withdrawals or the renewal of rolled-over interbank loans, especially when the bank is under suspicion of insolvency or when there is a temporary aggregate liquidity shortage. On the asset side, there is an uncertainty on the volume of new requests for loans that a bank will receive in the future. The bank may refuse some loan applicants but if these applicants are those of low credit risk, such rejection would lower bank profit. Credit rationing is not good for the economy as a whole. The third source of liquidity risk is the development of off-balance sheet 
operations. Examples include credit lines and other commitments. Positions taken by banks on derivative markets are even more important as these positions may generate extraordinary liquidity needs in future, especially in a period of crisis. The last sources of liquidity risk are large interbank payments (Rochet, 2008).

To ensure that the bank will be liquid at any time, adequate liquidity risk management is essential. The aims of liquidity risk management are to ensure that at all times an adequate corresponding balance between cash inflows and cash outflows, thus guaranteeing the solvency of the bank, to coordinate the issuing by the bank of short, medium and long term financing instruments, to optimize the costs of refinancing, striking a trade-off balance between liquidity and profitability, and to optimize, for banks structured as banking groups, the intra-group management of cash flows, with the aim of reducing dependence on external financial requirements, by means of cash pooling techniques or other optimization instruments (Ruozi and Ferrari, 2013). Bank liquidity in the Visegrad countries has been analyzed e.g. by Vodová (2013), Teplý et al. (2012) and Černohorská et al. (2012). The risk of contagion through the interbank market has been investigated e.g. by Allen and Gale (2000), Memmel and Sachs (2013) or Wells (2004).

Liquidity is sometimes confused with solvency. A solvent bank has a capital buffer which can absorb unexpected losses. To remain solvent, the value of the bank's assets must exceed its liabilities. A bank can become insolvent due to losses caused by any risk or factor. In order to maintain a sufficient level of solvency, banks have to fulfill capital adequacy rules.

A link exists between liquidity and solvency: a solvent bank should not have problems to obtain clients or interbank deposits. Once the capital adequacy worsens, the need to ensure sufficient liquidity becomes more important. Illiquid bank can rapidly become insolvent and vice versa.

The insufficient liquidity of a bank may lead to a situation where the majority of depositors intend to withdraw their funds which will cause a run on the bank. This situation is very dangerous even for healthy banks. In fact, no bank is able to repay all its depositors their funds if there is a run on the bank. Banks also provide medium and long term loans; therefore they maintain the level of cash and other liquid assets only at the necessary level. Additionally, the problem of one bank may quickly spread to the whole banking sector and result in a bank panic.

The importance of liquidity risk has been revised significantly during the global financial crisis. The financial crisis came after a stable period with sound macroeconomic conditions, where banks did not pay adequate attention to liquidity risk management (BIS, 2009). As a result of a continued drop in the market value of mortgage-backed securities from the subprime segment of the 
U.S. market and the announcement of problems in some European banks, the interbank market came under extreme strain. This crisis of confidence had the following consequences: interbank interest rates rose sharply; and many segments of the structured credit and mortgage market ceased to trade at all, making it difficult to price outstanding positions. In some cases, banks failed to raise enough cash through asset sales. As a result of liquidity hoarding of some banks, interbank lending became very difficult or impossible for many banks (Ewerhart and Valla, 2008).

In response to the illiquidity of the interbank market, the European Central Bank, U.S. Federal Reserve, and other national central banks had to respond. Unprecedented levels of liquidity support were required from central banks in order to sustain the financial system. Even with extensive support, a number of banks failed and were forced into mergers or a resolution was required (BIS, 2009; Černohorský et al., 2010).

A key characteristic of the financial crisis was the inaccurate and ineffective liquidity risk management. As usual after the crisis, some thoughts about the need for more appropriate liquidity risk regulation emerged. The aim of this paper is therefore to characterize the development of liquidity risk regulation.

The first section of this paper focuses on arguments for liquidity risk regulation. The second section describes the liquidity risk regulation before the financial crisis; the third section characterizes the current level of legislation in the Visegrad Countries. The last section focuses on prepared changes.

\section{Arguments for Liquidity Risk Regulation}

Some significant reasons exist as to why regulators should introduce a specific set of rules for liquidity risk (Vento and La Ganga, 2009; Banque de France, 2008):

Once a bank is perceived to be illiquid by the other banks in the same market and a supervisory authority and implicit or explicit commitments for maintaining the liquidity conditions in financial markets are missing, it would be very likely that the other participants in the interbank market would close the credit lines for the bank or would take back their loans. It is obvious that the existence of a supervisory authority which has an explicit goal in term of liquidity of the system and of the single financial intermediaries makes the other interbank market participants more confident of the fact that their interbank loans will be repaid.

The necessity of liquidity risk regulation is often motivated by the fact that depositors are not able to monitor over time whether their banks are liquid and whether they are in the position to withdraw their deposits. Adequate functioning of a supervisory authority therefore strengthens the confidence of depositors. 
The threat of systemic risk is the next argument for liquidity risk regulation. Banks are strictly interlinked through the payment system. In case of a temporary illiquidity of one bank, such a bank is not able to meet its obligations, including the interbank loans. This may create problems to all the other banks which provided loans to this illiquid bank (these loans cannot be paid). Since most depositors do not discriminate between healthy and illiquid banks, even healthy banks may get into trouble due to the banking panic and massive deposit withdrawals. Ewerhart and Valla (2008) indicated symptoms which show an increase of the contagious risk: liquidation of interbank deposits in response to unexpected deposit withdrawals, adverse selection in interbank market when information about the solvency of borrowers is imperfect, limited capacity of financial markets to absorb assets sales, inefficiency of asset liquidation and strength of direct balance sheet interlinkages.

Another reason why regulating liquidity risk is the fact that banks have no incentives to hold adequate amounts of liquid assets is because: liquidity is costly, especially when competition drives the search for higher returns on equity; liquidity shortages are very low probability events; and there is a perception that central banks will step in and provide liquidity support if and when it is needed (the moral hazard argument). The liquidity requirements can be seen as a way of sharing the costs of the public good of liquidity and financial stability between the private and the public sector. This would help to mitigate the moral hazard and prevent providing a liquidity support to illiquid banks.

Finally, stronger liquidity requirements would reduce the strategic uncertainty affecting banks actions, since they would be able to withstand larger liquidity shocks. Liquidity risk regulation increases the volume of liquid assets held by banks. As it is evident from Figure 1, with a higher level of liquidity risk regulation (horizontal axis), bank liquidity is increasing (vertical axis).

Figure 1 The Relationship between the Level of Regulation and the Amount of Liquidity Held

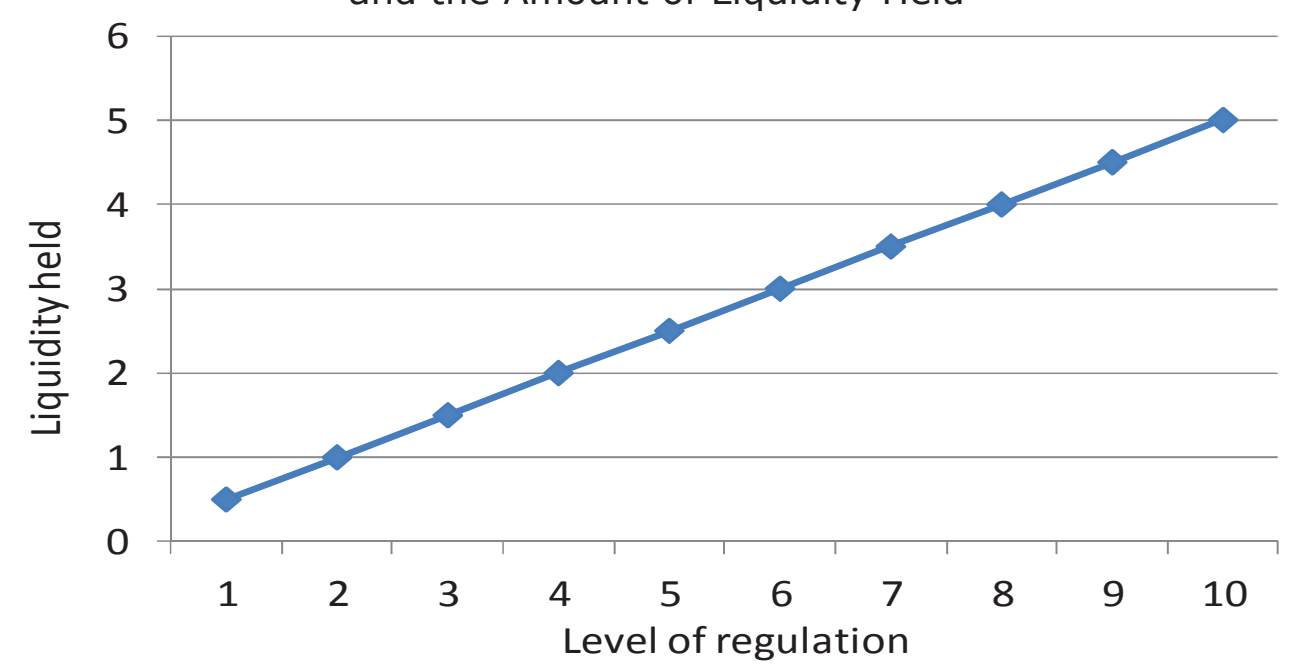

Source: authors' processing based on Vento and La Ganga (2009, p. 112) 


\section{Development of Liquidity Risk Regulation until the Global Financial Crisis}

Although regulators pay considerable attention to the credit and market risk, they focus on liquidity risk only gradually. Only in 1992, the Basel Committee on Banking Supervision has defined a framework for measuring and managing liquidity. Despite the main focus of the document on large and internationally active banks, some recommendations (such as good management information systems, analysis of net funding requirements under alternative scenarios, diversification of funding sources and contingency planning) were addressed to banks of any size or scope of activities, as crucial elements of strong liquidity management (BIS, 1992).

In 2000, the previous document was updated. The Basel Committee stressed the importance of liquidity managements in banks, pointed out the importance of developing different approaches to managing liquidity on a daily basis and different procedures in case of a liquidity crisis, the importance of measuring and monitoring net funding requirements and the interdependence of liquidity risk and other banking risks. From fourteen principles for liquidity risk management, four principles were related to development of an organizational structure for managing liquidity, three principles focused on measuring and monitoring of net funding requirements and two principles on foreign currency liquidity management. Another five principles covered contingency planning, managing market access, internal controls for liquidity risk management, role of public disclosure in improving liquidity and role of supervisors (BIS, 2000).

In 2006, the Joint Forum of the Basel Committee on Banking Supervision, International Organization of Securities Commissions and International Association of Insurance Supervisors (Joint Forum) focused on the liquidity risk management in financial groups and on the impact of financial derivatives and off-balance sheet activities on liquidity risk. Considerable attention has been paid to stress testing. Based on data of 40 large and complex financial groups, the Joint Forum came to the conclusion that stress tests of banks mostly examine the resilience of banks against possible bank run, modeled by the outflow of retail deposits in single digit percentage. In exceptional cases, banks tested outflow of between 10 and 20 percent of retail deposits. For corporate, bank and government deposits, which tend to be uninsured, typical worst-case scenarios reflect outflows of between 20 percent and 50 percent. Some banks test some other activities in the market (BIS, 2006).

Despite this, the procedures and rules of regulatory authorities in each country more or less differed. In December 2006, the Basel Committee established the Working Group on Liquidity whose task was to evaluate these differences. The market turmoil that began in mid-2007 however showed that the existing models of banks are not able to effectively predict liquidity crises and contingency plans 
do not consider really extreme market developments. The original mandate of the Working Group was expanded and the Working Group should observe the strengths and weaknesses of liquidity risk management in times of difficulty. These observations were published in February 2008. The Working Group highlighted the increasing reliance of banks on funds obtained from capital markets (which are potentially a more volatile source of funding than traditional retail deposits), the growth and product range of securitization (which on the one hand replaces illiquid loans by liquid cash but on the other hand, the dependence of banks on the market development grows), significantly higher use of complex financial instruments such as credit derivatives (where it is much more difficult to predict their cash flows, especially during market turbulence period) and greater cross-border cash flows (which increase the banks' reliance on international financial markets and the risk that the potential liquidity problems can be quickly transferred from one banking sector to another) (BIS, 2008a).

The Working Group also updated the principles for the liquidity risk management. These principles were published by the Basel Committee in September 2008. Seventeen principles emphasize the importance of establishing a liquidity risk tolerance; the maintenance of an adequate level of liquidity, including through a cushion of liquid assets; the necessity of allocating liquidity costs, benefits and risks to all significant business activities; the identification and measurement of the full range of liquidity risks; the design and use of severe stress test scenarios; the need for a robust and operational contingency funding plan; the management of intraday liquidity risk and collateral and public disclosure in promoting market discipline (BIS, 2008b).

\section{Current Level of Liquidity Risk Regulation in the Visegrad Countries}

These principles are currently implemented also in the law of the Visegrad countries - liquidity risk regulation can be found in the following documents:

- Decree No. 123/2007 Coll., stipulating the prudential rules for banks, credit unions and investment firms (in the Czech Republic),

- Recommendation No. 2/2000 of the President of the Hungarian Financial Supervisory Authority on Credit Institutions' Asset and Liability Management and the Management of Market Risks (in Hungary),

- Resolution No. 386/2008 of the Polish Financial Supervision Authority on the establishment of liquidity standards binding for banks (in Poland),

- Decree No. 18/2008 of Národná banka Slovenska on Liquidity of Banks and Branch Offices of Foreign banks and on Process of Liquidity Risk Management of Banks and Branch Offices of Foreign Banks and on amendment of Decree of Národná banka Slovenska No. $11 / 2007$ on Submission of Statements, Reports and Other 
Disclosures by Banks, Branches of Foreign Banks, Securities Dealers and Branches of Foreign Securities Dealers for Supervision and Statistical Purposes (in Slovakia).

In accordance with this legislation, Czech, Hungarian, Polish, and Slovak banks are required to establish and maintain policies and principles for the continuous and forward-looking measurement and management of the net liquid position (i.e. an excess or shortage of funds within stipulated time bands) so that it is possible to measure and compare the inflow and outflow of cash funds and to monitor net cash flows on a daily basis. Banks measure and monitor the liquidity risk in all main individual currencies with which they work with. If the bank finances assets held in one currency through liabilities held in another currency, it shall analyze the market conditions that may influence its access to the foreign exchange market. Depending on the size of the bank, its financial situation, the nature, scope and complexity of the activities performed, each bank has to set limits for liquidity risk management; both as an aggregate for all currencies and individually for each main currency with which it works with. Banks must have sufficiently elaborated strategies for the identification, measurement, management and monitoring of liquidity risk in an appropriate set of time bands, in a way to ensure the maintaining of an adequate liquidity buffer. These strategies must be selected in a way that they correspond to the complexity and the risk profile of the bank and to the accepted level of risk. Banks have to consider the possibilities by using various tools to mitigate liquidity risk and to stabilize and diversify their financial resources. For this purpose, banks shall in particular establish and maintain regular contacts with important creditors, verify the degree of reliability of the individual financial resources or monitor and maintain the opportunities to access the market for the purpose of selling their assets.

Banks must also have implemented scenarios for liquidity risk management and plans for extraordinary crisis situations. While preparing the scenario for liquidity risk management, the bank has to estimate the volume and structure of assets, liabilities and off-balance sheet items. The scenario must be regularly verified with regard to changing internal or external conditions. Changes in the estimates shall cause the scenario to be modified. To be able to manage liquidity risk in extraordinary crisis circumstances, each bank must have a contingency plan. The contingency plan shall contain specification of precise and timely information flows, clear demarcation of responsibilities and powers, possible methods for influencing the evolution of assets, liabilities and off-balance sheet items, the method of communication with important creditors, business partners, other persons, customers and the public, and the specification of reserve financial resources. The plan should be regularly tested and updated taking into account changing internal or external conditions. 


\section{Prepared Changes in the Liquidity Risk Regulation}

The next step in the liquidity risk regulation was made in December 2010, when the Basel Committee issued the Basel III rules. One part of these rules modifies the capital adequacy rules and the second part strengthens the liquidity risk regulation. According to the Basel Committee (BIS, 2010), the financial crisis showed the importance of liquidity to the proper functioning of financial markets and the banking sector. Prior to the crisis, asset markets were buoyant and funding was readily available at low cost. The rapid reversal in market conditions illustrated how quickly liquidity can evaporate and that illiquidity can last for an extended period of time. The banking sector came under severe stress, which necessitated central bank action to support both the functioning of money markets and, in some cases, individual institutions. Basel III rules should prevent the recurrence of such situations through these areas of regulation: minimum standards of liquidity (LCR - Liquidity Coverage Ratio and NSFR - Net Stable Funding Ratio) and monitoring tools to assess liquidity risk. The objective of these categories of tools is to raise banks' resilience to the liquidity stress (Ruozi and Ferrari, 2013).

The Liquidity Coverage Ratio (LCR) has been developed to ensure that a bank maintains an adequate level of unencumbered, high-quality liquid assets that can be converted into cash to meet its liquidity needs for a 30 calendar day time horizon under a significantly severe liquidity stress scenario specified by supervisors. By the $30^{\text {th }}$ day, it is assumed that appropriate corrective actions have been taken by the management and/or supervisors, and/or the bank has resolved its issues in an orderly way. The Liquidity Coverage Ratio is defined as follows:

$$
L C R=\frac{\text { Stock of high-quality liquid assets }}{\text { Total net cash outflows over the next } 30 \text { calendar days }} \geq 100 \%
$$

Stock of high-quality liquid assets are unencumbered assets with low market and credit risks, which can be easily valuated on a basis of publicly available data; their prices have low correlation with risky assets and these assets are listed on a developed and recognized exchange market. Such assets should have an active and sizable market and historically, the market has shown tendencies to move into these types of assets in a systemic crisis. High-quality liquid assets are divided into two categories. Level 1 assets include cash, central bank reserves, and marketable securities representing claims on or claims guaranteed by sovereigns, central banks, non-central governments, the Bank for International Settlements, the International Monetary Fund, the European Commission or multilateral development banks (after satisfying some conditions). Level 1 assets can be comprised without any limit. Level 2 assets, such as marketable securities representing claims on or claims guaranteed by sovereigns, central banks, noncentral government or multilateral development banks and corporate and covered bonds (again after satisfying some conditions) can be comprised to $40 \%$ of their 
value. Supervisors may also choose to include within Level 2 an additional class of assets: Level 2B assets. Level 2B assets includes residential mortgage backed securities, corporate debt securities (including commercial paper) and common equity shares (after satisfying some conditions) and should comprise no more than $15 \%$ of the total stock of high-quality liquid assets. They must also be included within the overall $40 \%$ cap on Level 2 assets.

The total net cash outflows are defined as the total expected cash outflows minus total expected cash inflows in the specified stress scenario for the subsequent 30 calendar days. The crisis scenario used by banks should simulate mainly the effects of the run-off of a proportion of retail deposits, a partial loss of unsecured wholesale funding capacity, a partial loss of secured short-term financing, additional contractual outflows that would arise from a downgrade in the bank's public credit rating, increases in market volatility, unscheduled draws on committed but unused credit and liquidity facilities that the bank has provided to its clients and the potential need for the bank to buy back debt. However, it is assumed that banks will conduct their own stress tests to assess the level of liquidity they should hold beyond this minimum, and construct their own scenarios that could cause difficulties for their specific business activities. In order to prevent banks from relying solely on anticipated inflows to meet their liquidity requirement, and also to ensure a minimum level of high-quality liquid assets holdings, the amount of inflows that can offset outflows is capped at $75 \%$ of total expected cash outflows. This requires a bank to maintain a minimum amount of stock of high-quality liquid assets equal to $25 \%$ of the total net cash outflows (BIS, 2010).

The Liquidity Cover Ratio should be reported to supervisors at least monthly, with the operational capacity to increase the frequency to weekly or even daily in stressed situations at the discretion of the supervisor (BIS, 2013a).

The LCR standard should be applied from the beginning of $1^{\text {st }}$ January 2015 . The minimum required value will initially be only $60 \%$. Each year, this value will increase gradually and the value of $100 \%$ must be reached by banks as of $1^{\text {st }}$ January 2019 (Table 1). This enables banks to adapt their activities and to fulfill regulatory requirements (BIS, 2013b).

Table 1 Minimum Requirements for Liquidity Coverage Ratio

\begin{tabular}{lccccc}
\hline & $\mathbf{2 0 1 5}$ & $\mathbf{2 0 1 6}$ & $\mathbf{2 0 1 7}$ & $\mathbf{2 0 1 8}$ & $\mathbf{2 0 1 9}$ \\
\hline $\begin{array}{l}\text { Minimum required } \\
\text { values of LCR }\end{array}$ & $60 \%$ & $70 \%$ & $80 \%$ & $90 \%$ & $100 \%$ \\
\hline
\end{tabular}

Source: BIS (2013b)

The aim of the Net Stable Funding Ratio (NSFR) is to ensure that long-term assets are funded with at least a minimum amount of stable liabilities in relation to their liquidity risk profiles. The NSFR has a time horizon of one year and has 
been developed to provide a sustainable maturity structure of assets and liabilities and is defined as follows:

$$
N S F R=\frac{\text { Available amount of stable funding }}{\text { Required amount of stable funding }}>100 \%
$$

The available amount of stable funding must therefore be at least equal to the required amount of stable sources. Available stable funding includes capital, preferred stock with maturity of equal to or greater than one year, liabilities with effective maturities of one year or greater, that portion of non-maturity deposits, term deposits and wholesale funding with maturities of less than one year that would be expected to stay with the institution for an extended period in an idiosyncratic stress event. These sources of funding are divided into five categories according to their stability. Each category has a different risk weight (ASF factor) which lowers the value of this source of funding, depending on its maturity and volatility.

Required stable funding can be expressed as the value of illiquid assets and securities held and financed by the bank; off-balance sheet items should be considered too. Required stable funding can be measured as the sum of the value of assets held and funded by the bank, multiplied by a specific required stable funding factor (RSF factor) assigned to each particular asset type (assets that are more liquid and more readily available to act as a source of extended liquidity in the stressed environment receive lower RSF factors) (BIS, 2010). The Net Stable Funding Ratio will be introduced from the beginning of $1^{\text {st }}$ January 2018. Its value must be greater than 100\% (BIS, 2013b).

These two standards of liquidity establish minimum levels of liquidity for internationally active banks. National supervisory authorities are free to require higher minimum levels of liquidity (BIS, 2010).

Besides these two ratios, BIS (2010) has also developed a set of monitoring tools for assessing liquidity risk:

- Contractual maturity mismatch, with the aim to identify the gap between the contractual inflows and outflows of liquidity for defined time bands. These maturity gaps indicate how much liquidity a bank would potentially need to raise in each of these time bands if all outflows occurred at the earliest possible date.

- Concentration of funding, with the aim to identify those sources of wholesale funding that are of such significance that withdrawal of this funding could trigger liquidity problems. It is good to focus not only funding liabilities sources from each significant counterparty, but also on funding liability sources from each significant product/instrument and on lists of asset and liability amounts by significant currencies.

- Available unencumbered assets, which can be used as collateral to raise additional secured funding in secondary markets and/or are 
eligible at central banks and as such may potentially be an additional source of liquidity for the bank.

- Liquidity Coverage Ratio by significant currencies, which allows the bank and the supervisor to track potential currency mismatch issues that could arise.

- Market-related monitoring tools which are high frequency market data with little or no time lag that can be used as early warning indicators in monitoring potential liquidity difficulties at banks. The bank can focus on market-wide information (such as equity prices, debt markets, foreign exchange markets and commodity markets development), information on the financial sector (mainly equity and debts) and bank-specific information (information about equity prices, credit default swap spreads, money-market trading prices, the situation of roll-overs and prices for various lengths of funding, the price/yield of bank debenture and/or subordinated debt in the secondary market can be valuable).

Basel III recommendations will be implemented into European law through the Directive of the European Parliament and of the Council on the access to the activity of credit institutions and the prudential supervision of credit institutions and investment firms and amending Directive 2002/87/EC of the European Parliament and of the Council on the supplementary supervision of credit institutions, insurance undertakings and investment firms in a financial conglomerate; which will replace Directives 2006/48/EC and 2006/49/EC, and Proposal for a regulation of the European Parliament and of the Council on prudential requirements for credit institutions and investment firms.

It is expected (and some effects are already visible) that the new liquidity risk regulation will particularly affect the profitability, asset structure, business mix and liability structure of banks (Ruozi and Ferrari, 2013). Barell et al. (2009) quantified the impact of the new regulation with cost-benefit analysis. Costs include cost to banks (because of the necessity to adapt the structure of assets and liabilities) and social costs. Social costs are the result of the impact of the new regulation on the growth rate of gross domestic products: higher lending margins of banks have negative impact on consumptions of households and investments of companies. Benefits are in terms of reducing the probability of a banking crisis. Comparing costs and benefits, authors came to a conclusion that there is a positive net benefit from regulatory tightening, i.e. despite the expected costs, the rules of Basel III as a whole should be beneficial. Other possible impacts of the Basel III rules are discussed e.g. in Šútorová and Teplý (2013) or Zimková (2010). 


\section{Conclusions}

The aim of this paper was to characterize the development of liquidity risk regulation. There are many reasons why regulators should introduce rules for liquidity risk: an illiquid bank is not able to obtain a loan on the interbank market; depositors are not able to monitor the liquidity of their bank; banks have no incentives to hold a sufficient buffer of liquid assets; stronger liquidity requirements reduce the probability of liquidity shocks and lower the threat of systemic risk.

Although regulators pay considerable attention to the credit and market risk, they focus on liquidity risk only gradually. The first framework for measuring and managing liquidity has been defined by the Basel Committee on Banking Supervision in 1992. There were some improvements in 2000, 2006 and 2008.

In the Visegrad countries, banks are required to establish and maintain policies and principles for the continuous and forward-looking measurement and management of the net liquid position on a daily basis and in all main currencies with which they work with. Each bank has to set limits for liquidity risk management. Banks must have sufficient strategy for liquidity risk management. Banks have to consider the possibilities of liquidity risk mitigation; they must stabilize and diversify their financial resources. Banks also must have implemented scenarios for liquidity risk management and contingency plans for extraordinary crisis situations.

In December 2010, the Basel Committee on Banking Supervision issued the Basel III rules which will strengthen the liquidity risk regulation. Basel III rules should prevent the recurrence of crisis situation through these areas of regulation: minimum standards of liquidity (LCR - Liquidity Coverage Ratio and NSFR - Net Stable Funding Ratio) and monitoring tools to assess liquidity risk. The LCR has been developed to ensure that a bank maintains an adequate level of unencumbered, high-quality liquid assets that can be converted into cash to meet its liquidity needs for a 30 calendar day time horizon under a significantly severe liquidity stress scenario specified by supervisors. The LCR standard should be applied from the beginning of $1^{\text {st }}$ of January 2015 . The minimum required value would increase gradually from $60 \%$ up to $100 \%$ as of $1^{\text {st }}$ January 2019 .

The NSFR focuses on liquidity in a longer-term time horizon. According to this ratio, the available amount of stable funding must be at least equal to the required amount of stable sources. The Net Stable Funding Ratio will be introduced from the beginning of $1^{\text {st }}$ January 2018 and its value must be greater than $100 \%$.

A set of monitoring tools for assessing liquidity risk may identify the potential sources of liquidity risk and may act as an early warning signal. The set of indicators includes contractual maturity mismatch, concentration of funding, 
available unencumbered assets, LCR by significant currency, and market-related indicators.

These new rules will be reflected in European law through the directives which will be implemented also into the legislation of the Visegrad Countries.

\section{Acknowledgments}

This paper was prepared with financial support from the Czech Science Foundation (Project GAČR P403/11/P243: Liquidity risk of commercial banks in the Visegrad countries).

\section{References}

Allen, F. and Gale, D. (2000). Financial Contagion. Journal of Political Economy, 108(1), pp. 1-33.

Banque de France (2008). Competition and liquidity crises. In: Banque de France Financial stability Review. Paris: Banque de France, pp. V-VI.

Barrell, R., Davis, E. P., Fic, T., Holland, D., Kirby, S. and Liadze, I. (2009). Optimal regulation of bank capital and liquidity: how to calibrate new international standards. FSA Occasional Paper, 38.

BIS (1992). A Framework for Measuring and Managing Liquidity. Basel: Bank for International Settlements.

BIS (2000). Sound Practices for Managing Liquidity in Banking Organisations. Basel: Bank for International Settlements.

BIS (2006). The Management of Liquidity Risk in Financial Groups. Basel: Bank for International Settlements.

BIS (2008a). Liquidity Risk: Management and Supervisory Challenges. Basel: Bank for International Settlements.

BIS (2008b). Principles for Sound Liquidity Risk Management and Supervision. Basel: Bank for International Settlements.

BIS (2009). International Framework for Liquidity Risk Measurement, Standards and Monitoring. Basel: Bank for International Settlements.

BIS (2010). Basel III: International Framework for Liquidity Risk Measurement, Standards and Monitoring. Basel: Bank for International Settlements.

BIS (2013a). Basel III: The Liquidity Coverage Ratio and liquidity risk monitoring tools. Basel: Bank for International Settlements.

BIS (2013b). Basel III Phase-in Arrangements. Available from: http://www.bis. org/bcbs/basel3/basel3_phase_in_arrangements.pdf.

Černohorská, L., Teplý, P. and Vrábel, M. (2012). The VT Index as an Indicator of Market Liquidity Risk in Slovakia. Journal of Economics, 60(3), pp. 223-238. 
Černohorský, J., Teplý, P. and Vrábel, M. (2010). Liquidity Market Support during the Global Crisis. Scientific Papers of the University Pardubice, 17(2), pp. 39-49.

Ewerhart, C. and Valla, N. (2008). Financial Market Liquidity and the Lender of Last Resort. In: Banque de France Financial Stability Review. Paris: Banque de France, pp. 133-148.

Memmel, C. and Sachs, A. (2013). Contagion in the Interbank Market and its Determinants. Journal of Financial Stability, 9(1), pp. 46-54.

Rochet, J. C. and Vives, X. (2004). Coordination Failures and the Lender of Last Resort: Was Bagehot Right After All? Journal of the European Economic Association, 2(6), pp. 1116-1147.

Ruozi, R. and Ferrari, P. (2013). Liquidity Risk Management in Banks. Economic and Regulatory Issues. Heidelberg: Springer.

Šútorová, B. and Teplý, P. (2013). The Impact of Basel III on Lending Rates of EU Banks. Czech Journal of Economics and Finance, 60(3), pp. 226-243.

Teplý, P., Vrábel, M. and Černohorská, L. (2012). The VT Index as an Indicator of Market Liquidity Risk in Slovakia. Ekonomický časopis, 60(3), pp. 223-238.

Vento, G. A. and La Ganga, P. (2009). Bank Liquidity Risk Management and Supervision: Which Lessons from Recent Market Turmoil? Journal of Money, Investment and Banking, 2009(10), pp. 79-126.

Vodová, P. (2013). Liquid Assets in Banking: What Matters in the Visegrad Countries? E+M Ekonomie a Management, 16(3), pp. 113-129.

Wells, S. (2004). Financial Interlinkages in the United Kingdom's Interbank Market and the Risk of Contagion. Bank of England Working Paper No. 230.

Zimková, E. (2010). Vplyv Basel III na Reguláciu Bánk. Acta Aerarii Publici, 7(2), pp. 89-100.

Decree No. 18/2008 of Národná banka Slovenska on Liquidity of Banks and Branch Offices of Foreign banks and on Process of Liquidity Risk Management of Banks and Branch Offices of Foreign Banks and on amendment of Decree of Národná banka Slovenska No. 11/2007 on Submission of Statements, Reports and Other Disclosures by Banks, Branches of Foreign Banks, Securities Dealers and Branches of Foreign Securities Dealers for Supervision and Statistical Purposes. Available from: http://www.nbs.sk/en/financial-market-supervision/ banking-sector-supervision/legislation/decrees/decree-of-narodna-bankaslovenska-of-28-october-2008.

Recommendation No. 2/2000 of the President of the Hungarian Financial Supervisory authority on Credit Institutions' Asset and Liability Management and the Management of Market Risks. Available from: http://www.pszaf.hu/en/left_ menu/regulation/pszafen_recommendations/pszafen_guidelines_20050812_3.ht $\mathrm{ml}$. 
Resolution No. 386/2008 of the Polish Financial Supervision Authority on the establishment of liquidity standards binding for banks. Available from: http://www.knf.gov.pl/en/Images/Resolution_386_2008_tcm81-25375.pdf.

Proposal for a regulation of the European Parliament and of the Council on prudential requirements for credit institutions and investment firms. Available from: http://eur-lex.europa.eu/LexUriServ/LexUriServ.do?uri=COM:2011:0452: FIN:en:PDF.

Proposal for a Directive of the European Parliament and of the Council on the access to the activity of credit institutions and the prudential supervision of credit institutions and investment firms and amending Directive 2002/87/EC of the European Parliament and of the Council on the supplementary supervision of credit institutions, insurance undertakings and investment firms in a financial conglomerate. Available from: http://eur-lex.europa.eu/LexUriServ/LexUriServ. do?uri=COM:2011:0453:FIN:en:PDF.

Decree No. 123/2007 Coll., stipulating the prudential rules for banks, credit unions and investment firms. Available from: http://www.cnb.cz/miranda2/ export/sites/www.cnb.cz/en/legislation/prudential_rules/download/vyhlaska_para _cast_1_en.pdf. 